\title{
Chlorophyll $a$ and total nutrients distribution from surface waters in Romanian MONITOX network in 2019 and 2020
}

\author{
Cosmin Spiridon ${ }^{1}$, Adrian Burada ${ }^{1}$, Liliana Teodorof ${ }^{1}$, Cristina Despina $^{1}$, \\ Daniela Seceleanu - Odor ${ }^{1}$, Marian Tudor ${ }^{1}$, Antoaneta Ene ${ }^{2,3}$ \\ ${ }^{1}$ Danube Delta National Institute, 165 Babadag Street, Tulcea, Romania, adrian.burada@ddni.ro \\ ${ }^{2}$ INPOLDE interdisciplinary research network, ReForm-UDJG Platform, Dunarea de Jos University of Galati, \\ 111 Domneasca St., 800201 Galati, Romania \\ ${ }^{3}$ Dunarea de Jos University of Galati, Faculty of Sciences and Environment, 47 Domneasca Street, 800008 \\ Galati, Romania \\ *Corresponding author: cosmin.spiridon@ddni.ro
}

\begin{abstract}
The development of chlorophyll $a$ is dependent on a number of physico-chemical factors with high sensitivity to changes in water properties. Among the factors that influence the development of chlorophyll the most important are $\mathrm{pH}$, temperature, solid suspensions, salinity, light, transparency, hydrology, and human activities. The sampling was carried out along the Danube from $\mathrm{km} \mathrm{375,} \mathrm{until} \mathrm{the} \mathrm{flow} \mathrm{of} \mathrm{the} \mathrm{three} \mathrm{arms} \mathrm{into} \mathrm{the} \mathrm{Black} \mathrm{Sea.} \mathrm{A}$ number of 25 points were selected along this length, which includes the eastern Pontic sector, the Predobrogean sector, and the Deltaic sector. The determinations were performed in June, in the years 2019 and 2020, a period in which the course of the Danube river usually has a tendency to reduce the flow. In the determinations performed along the Danube were identified low values of chlorophyll $a$ varying between $2.77 \mu \mathrm{g} / \mathrm{L}$ and 7.23 $\mu \mathrm{g} / \mathrm{L}$ in 2019 and between $1.98 \mu \mathrm{g} / \mathrm{L}$ and $9.91 \mu \mathrm{g} / \mathrm{L}$ in 2020, which correspond to quality class I according to the Order of the Minister of Waters and Environmental Protection 161 / 16.02.2006.
\end{abstract}

Keywords: Danube river, chlorophyll a, surface water, nutrients.

\section{INTRODUCTION} through.

The Danube is a very important part of the economy and environment all over the area it goes

Water quality is essential in the natural balance of a very large area.

The integrity of the structure and functions of the ecosystem is the most important both for protection and for knowing its evolution. The trophic structure and the biogenic elements mostly determine the water quality, thus being registered the disturbances from point sources or short or long term changes in the properties of the ecosystem [1].

During two expeditions performed on the Danube from Calarasi/Silistra to the discharge into the Black Sea on the three channels - Chilia, Sulina, and Sfantu Gheorghe - a number of 25 sampling and measurement points were selected. The following biological and chemical parameters were established for investigations: chlorophyll a, $\mathrm{pH}$, total nitrogen, and total phosphorus. They are closely related, chlorophyll a being dependent on the nutrient concentrations, and nutrients may have accumulations or may be consumed by chlorophyll [2,3].

The main objective of this study to evaluate the distribution of some nutrients in surface water in 2019 and 2020 from the Danube to the Black Sea. 
All the results from this study were obtained during the monitoring activities of ENI project eMS code BSB27 MONITOX (2018-2021), Joint Operational Programme Black Sea Basin 20142020.

\section{EXPERIMENTAL}

The Danube is the second largest river in Europe. The length, the morphology, and the fact that it passes through 10 countries makes the anthropic pressure to be immense. Transport, agriculture, and industry are some of the most important factors leading to irreversible changes in water quality.

From the end of 1970 until 1990, the nutrient emission from the anthropogenic sources along the Danube River strongly influences the amount of the nutrients accumulated into the Danube Delta's ecosystems $[4,5]$.

Determinations of chlorophyll a and $\mathrm{pH}$ were performed in situ using the submersible multiparameter Ysi Exo 2 at an approximate depth of $20 \mathrm{~cm}$ for 2-3 minutes [6].

The EXO2 probe is a multiparametric instrument that collects water quality data. The probe collects data with up to six sensors, each sensor measuring its parameters through a variety of electrochemical, optical, or physical detection methods. Depending on the user-defined settings, the EXO2 probe will collect data and store it on board the probe, transfer the data to a data collection platform, or transmit to the user's computer or portable EXO instrument via cable, USB connection, or Bluetooth connection.

During the national trip, 25 surface water samples were collected for nutrients analysis (Fig. $1)$.

The results were reported to the values corresponding to the Water Framework Directive, transposed in the Romanian legislation through Order 161/2006 [7].

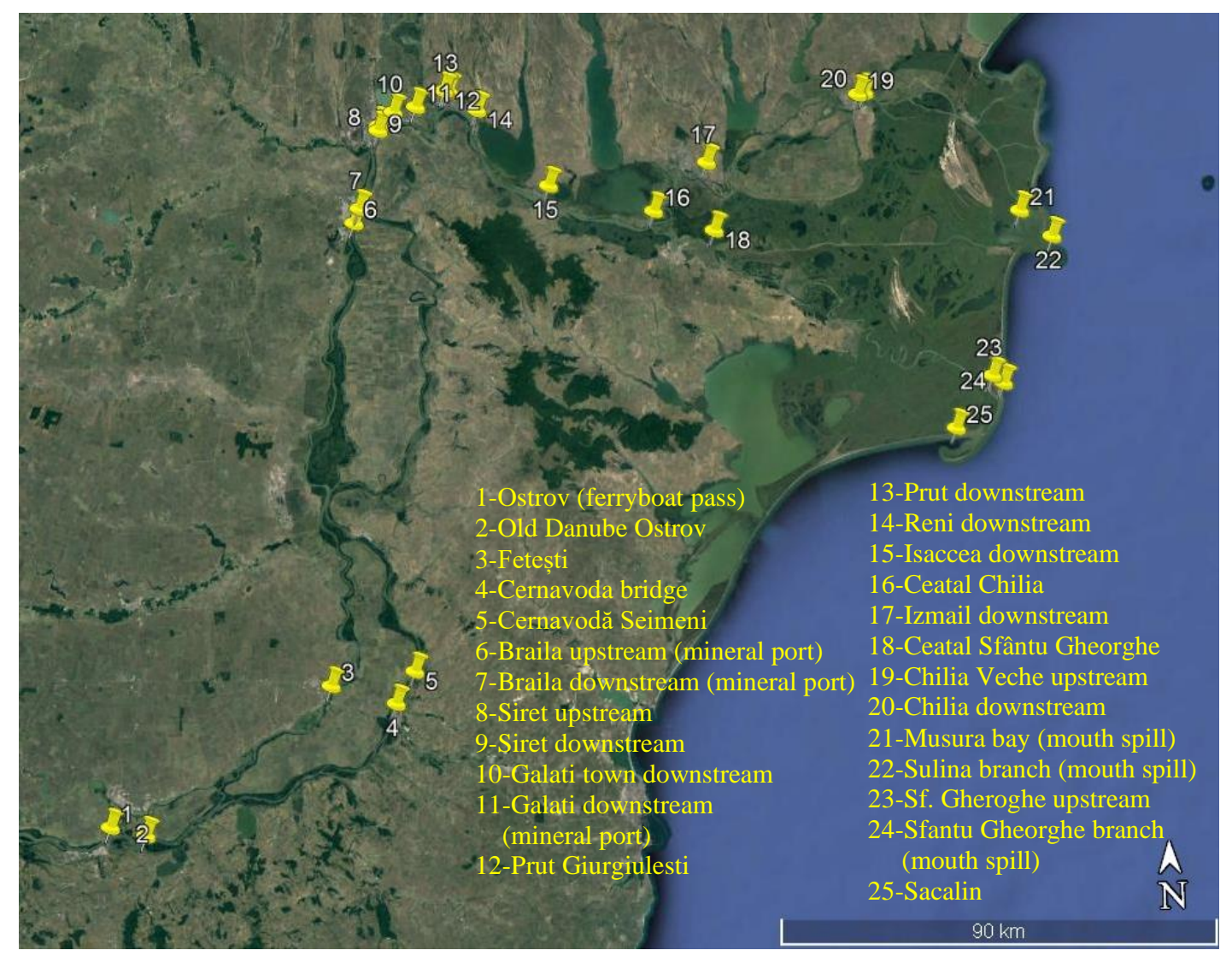

Fig. 1. Sampling points in Romanian MONITOX network 
For the analysis of total nitrogen, the samples were preserved on the field with $1 \mathrm{~mL} \mathrm{H}_{2} \mathrm{SO}_{4}$ $98 \%$, for $100 \mathrm{~mL}$ sample, stored at $4^{0} \mathrm{C}$, and analysed in the laboratory. Determination of nutrients dissolved was made on filtered samples and total forms on unfiltered samples using UV-VIS Lambda 10 Perkin Elmer spectrophotometer and ISO standards. The final results were expressed in $\mathrm{mg} / \mathrm{L}$. All the reagents have very good quality analytical grade. For quality assurance were made flow charts with the specific certified reference materials.

Determination of phosphorus content in surface waters was made according to SR EN 6878/2005, Water quality, Determination of phosphorus, Ammonium molybdate spectrometric method using UV-VIS Lambda 10 Perkin Elmer Spectrometer at $880 \mathrm{~nm}$. For total phosphorus, the samples were treated on unfiltered water. Ammonium molybdate and potassium antimonyl tartrate react in an acid medium with orthophosphate to form a heteropoly acid - phosphomolybdic acid - that is reduced to intensely blue coloured molybdenum by ascorbic acid (SR EN 6878 2005) [8].

\section{RESULTS AND DISCUSSION}

The results of the measurements related to the ecological status indicate a good and very good quality for most sampling and measurement points.

In 2019, based on the recorded total nitrogen concentrations, all the surface waters are framed in the good quality class, except for Cernavoda Bridge and Prut downstream (poor quality class). In 2020 , the water quality increased by 15 points, being classified in the second class, and in 10 points corresponding to the first quality class [7].

Total phosphorus also showed an improvement in quality as follows: 10 surface water in second class in 2019 and only 5 in 2020, and the other surface waters are framed in the first class (very good ecological status) (Table 1).

In 2019, total nitrogen (TN) showed a decreasing trend from the upstream of Danube towards the discharge into the Black Sea. The similar trend was observed in 2020, all the values being lower than those obtained for 2019 (Fig 2).

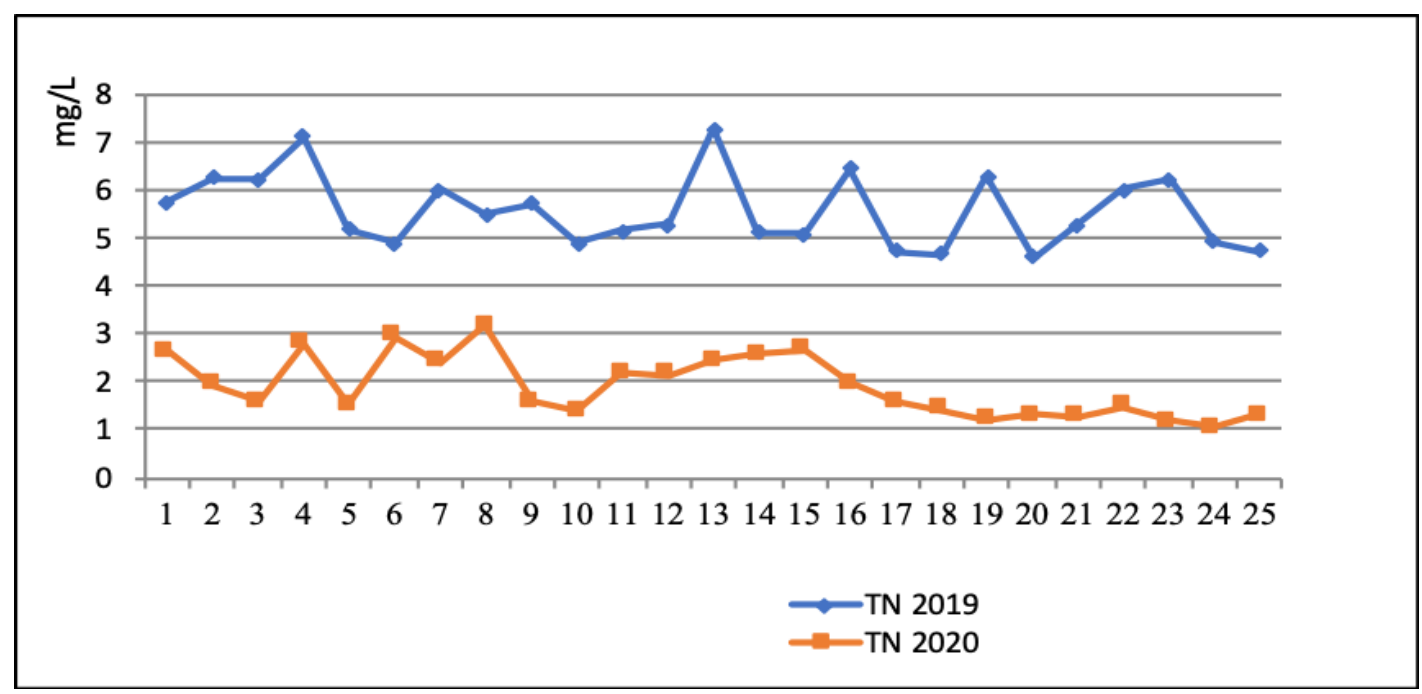

Fig. 2. Total nitrogen (TN) variation along the Danube River in 2019-2020

Total phosphorus (TP) concentration shows a decrease in 2020, except for 5 points. In the case of phosphorus, there is an increase in the concentration from upstream to downstream in both years, with an irregular variation between the sampling points (Fig. 3). 




Fig. 3. Total phosphorus (TP) variation along the Danube River in 2019-2020

Table 1. Total nutrients and chlorophyll concentrations and the corresponding quality class (blue - class I, very good; green - class II, good; yellow- class III, poor)

\begin{tabular}{|c|c|c|c|c|c|c|c|c|}
\hline \multirow[t]{2}{*}{ Area } & \multirow[t]{2}{*}{ No. } & \multirow[t]{2}{*}{ Sampling points } & \multicolumn{2}{|c|}{$\begin{array}{l}\text { Total Nitrogen, } \\
\text { mg/L }\end{array}$} & \multicolumn{2}{|c|}{$\begin{array}{c}\text { Total } \\
\text { Phosphorus, } \\
\text { mg/L } \\
\end{array}$} & \multicolumn{2}{|c|}{$\begin{array}{c}\text { Chl. a, } \\
\mu \mathrm{g} / \mathrm{L}\end{array}$} \\
\hline & & & 2019 & 2020 & 2019 & 2020 & 2019 & 2020 \\
\hline $\begin{array}{l}\text { Lower } \\
\text { Danube } \\
\text { RO-BG }\end{array}$ & 1 & Ostrov (ferryboat pass) & 5.751 & 2.640 & 0.115 & 0.116 & 3.27 & 4.89 \\
\hline \multirow{10}{*}{$\begin{array}{l}\text { Lower } \\
\text { Danube RO }\end{array}$} & 2 & Old Danube Ostrov & 6.260 & 1.940 & 0.117 & 0.091 & 3.09 & 2.93 \\
\hline & 3 & Fetesti & 6.222 & 1.568 & 0.156 & 0.103 & 3.46 & 5.87 \\
\hline & 4 & Cernavoda bridge & 7.118 & 2.788 & 0.108 & 0.102 & 2.77 & 9.91 \\
\hline & 5 & Cernavoda Seimeni & 5.191 & 1.496 & 0.115 & 0.095 & 2.83 & 5.74 \\
\hline & 6 & Braila upstream (mineral port) & 4.888 & 2.936 & 0.126 & 0.096 & 4.04 & 6.72 \\
\hline & 7 & $\begin{array}{l}\text { Braila downstream (mineral } \\
\text { port) }\end{array}$ & 6.013 & 2.396 & 0.128 & 0.079 & 4.1 & 5.73 \\
\hline & 8 & Siret upstream & 5.501 & 3.172 & 0.139 & 0.172 & 5.23 & 4.35 \\
\hline & 9 & Siret downstream & 5.711 & 1.580 & 0.194 & 0.107 & 4.06 & 4.4 \\
\hline & 10 & Galati town downstream & 4.885 & 1.388 & 0.110 & 0.089 & 3.53 & 7.34 \\
\hline & 11 & $\begin{array}{l}\text { Galati downstream (mineral } \\
\text { port) }\end{array}$ & 5.147 & 2.188 & 0.134 & 0.266 & 3.06 & 5.56 \\
\hline \multirow{2}{*}{$\begin{array}{l}\text { Lower Prut } \\
\text { RO-MD } \\
\text { border }\end{array}$} & 12 & Prut Giurgiulesti & 5.289 & 2.152 & 0.145 & 0.061 & 3.87 & 7.72 \\
\hline & 13 & Prut downstream & 7.275 & 2.432 & 0.167 & 0.140 & 3.57 & 6.29 \\
\hline \multirow{8}{*}{$\begin{array}{l}\text { Danube } \\
\text { Delta RO- } \\
\text { UA border }\end{array}$} & 14 & Reni downstream & 5.115 & 2.564 & 0.134 & 0.117 & 3.67 & 2.83 \\
\hline & 15 & Isaccea downstream & 5.081 & 2.656 & 0.154 & 0.205 & 3.67 & 5.66 \\
\hline & 16 & Ceatal chilia & 6.437 & 1.964 & 0.145 & 0.128 & 4.59 & 2.41 \\
\hline & 17 & Izmail downstream & 4.711 & 1.564 & 0.174 & 0.118 & 4.3 & 3.20 \\
\hline & 18 & Ceatal Sf Gheorghe & 4.647 & 1.423 & 0.143 & 0.098 & 4.26 & 3.40 \\
\hline & 19 & Chilia Veche upstream & 6.272 & 1.228 & 0.145 & 0.121 & 3.54 & 3.65 \\
\hline & 20 & Aval Chilia Veche & 4.605 & 1.325 & 0.172 & 0.088 & 3.74 & 3.69 \\
\hline & 21 & Sf Gheorghe upstream & 5.285 & 1.264 & 0.168 & 0.184 & 3.77 & 2.96 \\
\hline \multirow{4}{*}{$\begin{array}{l}\text { Black Sea } \\
\text { area - RO }\end{array}$} & 22 & Musura bay (mouth spill) & 6.027 & 1.464 & 0.179 & 0.064 & 7.23 & 1.98 \\
\hline & 23 & Sulina branch (mouth spill) & 6.217 & 1.172 & 0.123 & 0.164 & 2.85 & 3.36 \\
\hline & 24 & $\begin{array}{l}\text { Sfantu Gheorghe branch } \\
\text { (mouth spill) }\end{array}$ & 4.941 & 1.044 & 0.152 & 0.139 & 3.63 & 3.04 \\
\hline & 25 & Sacalin & 4.735 & 1.300 & 0.194 & 0.113 & 3.75 & 4.07 \\
\hline
\end{tabular}


Chlorophyll a does not show significant variations in 2019. In 2020 a decrease can be observed towards the discharge into the Black Sea. The maximum value obtained was $9.91 \mu \mathrm{g} / \mathrm{L}$, corresponding to the first quality class (Fig. 4).

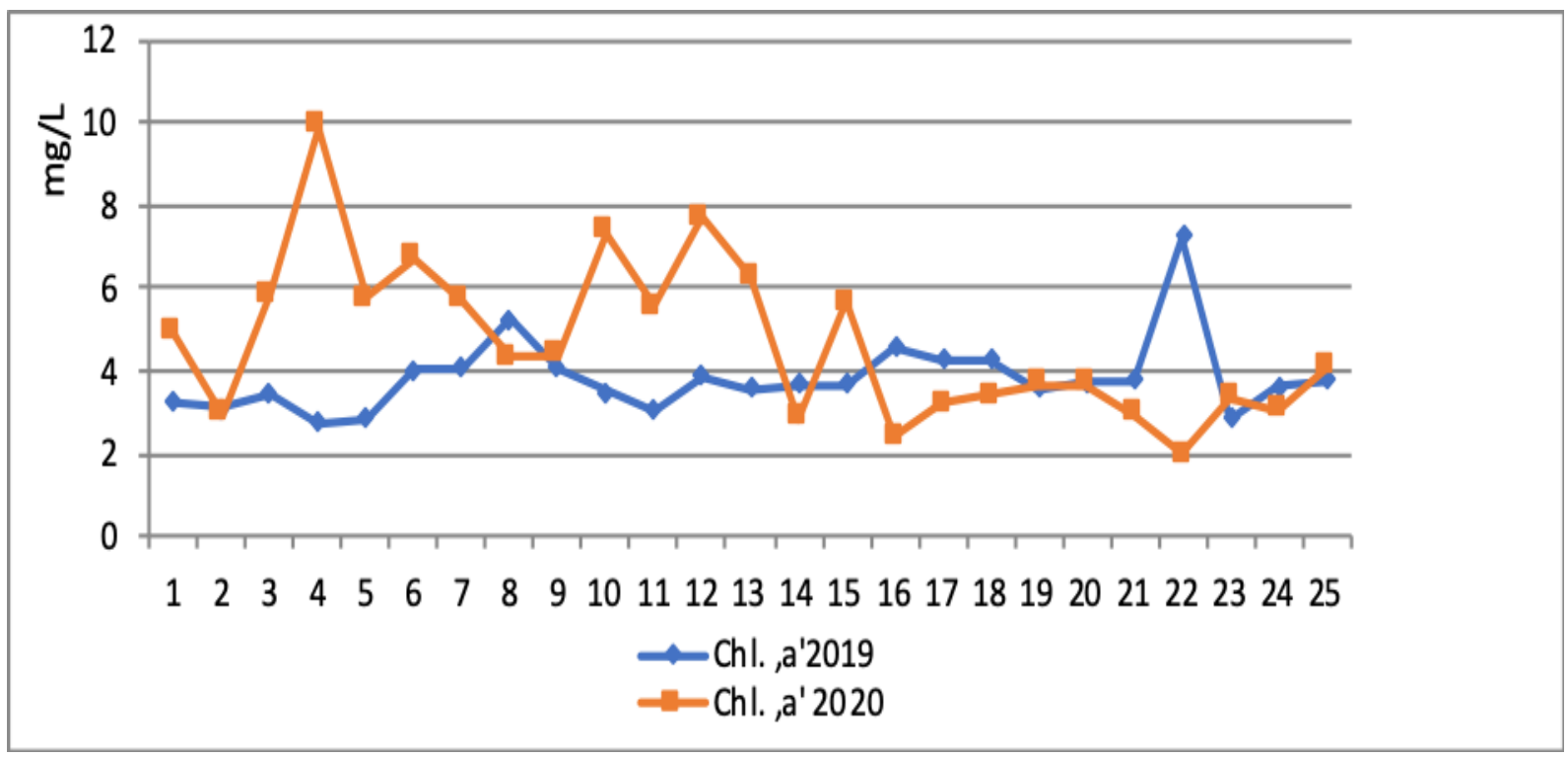

Fig. 4. Chlorophyll a variation along the Danube River in 2019-2020

\section{CONCLUSIONS}

From the nutrients point of view - ammonia, nitrate (expressed in nitrogen), dissolved phosphorus and total phosphorus - the surface waters had a very good and good ecological status. The downward trend towards the flow of the Danube into the Black Sea can be placed on reducing the anthropogenic impact, influenced by a lower industrial development. At the same time, the Danube Delta is an area of natural water treatment, through biological processes in aquatic ecosystems and beyond.

Acknowledgements: The authors would like to thank the funding of project BSB27-MONITOX (2018-2021), Joint Operational Programme Black Sea Basin 2014-2020.

\section{References}

1. Gâştescu P., Ştiucă R., Delta Dunarii Rezervatie a Biosferei, Ed. CD PRESS, Romania (2008) 400.

2. Codd G. A., Young F. M., Utkilen H. C., Europe: Cyanobacteria, cyanotoxins, their health significance and risk management. in: CYANONET A Global Network for Cyanobacterial Bloom and Toxin Risk Management Initial Situation Assessment and Recommendations, International Hydrological Programme-VI, 76, UNESCO Working Series SC-2005/WS/55, (2005) $71-93$.

3. Codd G. A., Jefferies T. M., Keevil C. W., Potter E. (eds.), Detection Methods for Cyanobacterial Toxins. The Royal Society of Chemistry (1994) $1-191$.

4. Ostberg W., Buijse A. D., Coops H., Ibelings B. W., Menting G. A. M., Staraș M., Bogdan L., Constantinescu A., Hanganu J., Năvodaru I., Török L., Ecological gradients in the Danube Delta lakes. - Present state and man-induced changes. RIZA raport 2000.015, The Netherland (2000) 3-168.

5. Tudor M., Spatiile verzi si rolul lor ecologic in ecosistemul urban Tulcea, Sc. Annals of the Danube Delta Institute (1996) 51-54. 
6. Tudor I.M., Ibram O., Török L., Covaliov S., Doroftei M., Tudor M., Năstase A., Năvodaru I., Metode de monitorizare a indicatorilor biologici în ecosistemele acvatice ale Deltei Dunării, cap. 3, in: Tudor I.-M. (ed.), Ghid metodologic de monitorizare a factorilor hidromorfologici, chimici și biologici pentru apele de suprafață din Rezervația Biosferei Delta Dunării, ISBN: 978-606-93721-8-0, Editura Centrul de Informare Tehnologică Delta Dunării, Tulcea (2015) 95-123.

7. Ordinul nr. 161 din 16.02.2006 al Ministerului Mediului si Gospodăriri Apelor pentru aprobarea Normativului privind clasificarea calitătii apelor de suprafaţă în vederea stabiliri istării ecologice a corpurilor de apă. IN: Monitorul Oficial al României, No. 511 (2006).

8. SR EN 6878/2005. Water quality. Determination of phosphorus. Ammonium molybdate spectrometric method (2005). 